\title{
Politics and the Development of Modern African Poetry
}

\author{
Friday A. Okon ${ }^{1}$ \\ ${ }^{1}$ Department of English, University of Uyo, Uyo, Nigeria \\ Correspondence: Friday A. Okon, Department of English, University of Uyo, Uyo, Nigeria. Tel: \\ 234-802-374-3852, 234-806-749-6485. E-mail: manfriday03@yahoo.com
}

Received: December 13, 2012 Accepted: February 7, 2013 Online Published: February 22, 2013

doi:10.5539/ells.v3n1p94 URL: http://dx.doi.org/10.5539/ells.v3n1p94

\begin{abstract}
Modern African poetry is poetry of commitment, and therefore, it has utilitarian value. It began as an intellectual response to the denigration of Africa and Africans by the white colonizers. From this point, there has been no going back, as African poetry has continued to be pressed into the service of the politics of the continent with a view to changing the prevailing poor conditions of the masses who suffer neglect at the hands of their ruling elite. However, in the current globalised world driven by ICT, focus has shifted to mirroring the degradation of the environment as a way of galvanizing political action towards preserving the ecosystem for the survival of man. This paper examines the relationship between politics and modern African poetry, from West to East and Southern Africa, and posits that politics is the substance while poetry is the vehicle of expression.
\end{abstract}

Keywords: politics, African, poetry, commitment, development, modern

\section{Introduction}

Modern African poetry, as any other poetry all over the world, has been used to express various emotions and themes ranging from love, death of a loved one, hope and faith, to praise of nature, amongst others; however, the political theme has tended to dominate it. It can be stated that modern African poetry has been used to express the problems, peculiarities and prospects of politics in the African world in the twentieth century and beyond. Politics in modern Africa dates back to the period of colonial conquest and partition of Africa by the Europeans in the late nineteenth century: through the colonial phase, to the neocolonial aberrations we find today in the name of independent African states. This, together with the cultural trauma it unleashed on the African mind through religion and education, form the basic material for modern African poetry, without prejudice to other germane themes.

Colonial politics transformed the largely independent African ethnic groups and welded them into large geopolitical units irrespective of compatibility, historical or cultural ties. The new states became largely independent by 1960 . However, the "new democratic" political system of governance imposed by the departing colonial powers was handed over in a hurry to the new African political elite; so, these new leaders did not have enough time to get acquainted with its workings. In view of the foregoing, what resulted after independence in the states across the continent was a farce: political thuggery, tribal genocide, corruption, civil wars, coups, and political assassinations. As Wauthier (1978: 289) comments:

The year of African independence was 1960 marking the end of European tutelage in seventeen colonial territories. Some fifteen years later, the number of coups d'état, mostly military, occurring in Africa was in the region of thirty, not counting the plots that were uncovered. The two richest and most populous countries in black Africa, Congo-Kinshasa (later Zaire) and Nigeria were torn by appalling civil wars triggered off by attempts at secession on the part of Katanga and Biafra respectively. In Ethiopia, the overthrow of the oldest monarchy in the world has not resolved the problem of Eritrea, where the guerrilla forces have continued their struggle to free their country from the tutelage of Addis Ababa. Three presidents, Jean Bedel Bokassa of the Central African Empire, Marcias N'guema of Equatorial Guinea and Idi Amin Dada of Uganda, have filled the columns of the international press with stories of bloodshed and buffoonery.

And in all this, what was the lot of the common man? Deplorable: full of misery and hardship, and the bitterness consequent on the betrayal of their hopes and dreams; or in the case of South Africa, due to the continuation of Apartheid.

In view of this situation the modern African poet cannot afford to be unconcerned. His energies have been 
committed to the portrayal of the salient issues and problems of his society. As Anyidoho (1979: 51), quoting Atukwei Okai, once declared:

...In Africa, the poet cannot afford to just play around with words. It is natural that he should handle some of the realities of his society.

Therefore, modern African poetry has largely been the poetry of commitment: commitment to the political configuration of the African world with a view to bringing about desired change. In other words, politics is the substance while poetry is the form par excellence of its portrayal.

This paper therefore, shall examine politics as the substance of modern African poetry starting with the pioneers at the beginning of the 20th century, through the post-independence phase. Emphasis shall also be given to the ideological influences on poets during each poetic phase.

\section{The Pioneers (Pre-Independence Echoes)}

From the beginning, modern African poetry has illuminated the political concerns of its history. Putting aside Benibengor Blay's imitative poetry, ${ }^{1}$ we find the politics of anti-colonial struggle highlighted in the poems of Gladys Casely-Hayford, R.E.G. Armattoe, D.C. Osadebay, Micheal Dei-Anang, and Vilakazi.

In the works of these early poets can be found the first echoes of nationalist protest against colonial rule. To this wise, these poets used African imagery and concepts to realize their aims. Examples are Gladys Casely Hayford's "Rejoice"; Dei-Anang's "Dear Africa"; Armattoe's "Africa", and Vilakazi’s "On the Gold Mines".

In Gladys Casely Hayford's "Rejoice" African nationalism is expressed. The persona exhorts Africans (blacks) to rejoice:

Rejoice and shout with laughter.

Throw all your burdens down,

If God has been so gracious

As to make you black or brown.

The persona attributes a great birth and a glorious heritage to Africa, and therefore urges all Africans to rejoice in spite of their present political denigrations. Therefore, Africa is painted in a positive light:

For you are a great nation,

A people of great birth

For where would spring the flowers

If God took away the earth?

Rejoice and shout with laughter

Throw all your burdens down

Yours is a glorious heritage

If you are black, or brown (West African Verse, p.5).

A similar vein runs through the poem of R. E. G. Armattoe: "Africa". In this poem, Africa is portrayed as a sad maiden:

I once saw a maiden dark and comely,

Sitting by the wayside, sad and lonely.

The poem portrays the helpless plight of Africa in the midst of an acquisitionist industrial Europe:

'I am neither sad nor lonely, 'she said,

'But living, Sir, among the deaf and dumb;

Relentlessly watching these shameless dead,

Makes my warm heart very cold and numb'. (WAV, p. 11).

Osadebay's "Who Buys my Thoughts" projects the thinking of Africa from the perspective of the masses and their basic problems:

Who buys my thoughts

Buys not a cup of honey 
That sweetens every taste;

He buys the throb,

Of Young Africa's soul,

The soul of teeming millions,

Hungry, naked, sick,

Yearning, pleading, waiting.

It is also the dilemma of young Africans caught in the clash of cultures:

Or restless youths who are born

Into deep and clashing cultures,

Sorting, questioning, watching.

Finally, it is the thoughts of the Nationalist struggle that seeks to rid the African continent of colonial rule:

...Buys the spirit of the age,

The unquenching fire that smoulders

And smoulders

In every living heart

That's true and noble of suffering;

It burns all over the earth,

Destroying, chastening, cleansing.

(WAV, pp. 15-16).

Also, in 'Young Africa's Plea', Osadebay argues against the preservation of African traditions and culture for their sociological allure to pamper European tastes:

Don't preserve my customs

As some fine curios

To suit some white historian's tastes.

Rather, let the African be modern by working with the whiteman's methods while doing his own thinking and being independent in every sense:

Let me play with the whiteman's ways

Let me work with the blackman's brains

Let my affairs themselves sort out.

It is only in this way that the African can regain his lost self-respect and face the world manfully. After all, those who denigrate Africa, in reality, fear her strength and talents in private:

Then in sweet rebirth

I'll rise a better man

Not ashamed to face the world.

Those who doubt my talents

In secret fear my strength

They know I am no less a man.

For these reasons, he calls on Africa's detractors to have a change of heart and give Africa her freedom; unconditional freedom of which there shall be nothing to regret:

Let them bury their prejudice,

Let them show their noble sides,

Let me have untrammeled growth,

My friends will never know regret 
And I, I never once forget. (WAV, p. 17).

Dei-Anang exhorts Africans to wake up from their long slumber and display their love for the continent, in his poem "Dear Africa". In addition, he points to the danger posed to Africa by its lure that has attracted foreigners (Whites) to colonise her:

Awake, thou sleeping heart!

Awake, and kiss

The Love-lorn brow

Of this ebon lass,

Dear Africa,

Whose virgin charms

Ensnare the love-lit hearts

Of venturing youth

From other lands. (WAV, p. 21)

The urgency of the situation is stressed:

Awake, sweet Africa

Demands thy love,

Thou sleeping heart!

... Know then, thou sleeping heart,

Dear Africa stands

Knocking at the door. (WAV, p. 21).

Vilakazi's poems deal with the South African situation of oppression and racism. Vilakazi was a protest poet who, according to Nkosi (1981:112) was one

among the founding members of the strongest protest movement which has been the marked feature of South African verse in more than a quarter of a century.

In his poem "On the Gold Mines" (translated from Zulu into English) the persona presents an interesting picture of a white foreman. He (the white foreman) is seen as the representative of his race and civilization: a civilization that is sterile, mechanical, inhuman and, at once, totally alien to the African and his environment:

Bellow you frenzied bulls of steel!

Far is the place where first you came to life

And - roasted by fiery furnace

Until you were ready and only ash remained-

Were quickly dispatched, and having crossed the sea

Were loaded on trucks, for puffing fuming engines

To bring you to Goli, place of gold and us.

Loudly you bellowed, till we, like frightened dassies

Swarming towards you, answered your strident summons

(Tasks and Masks, pp. 111-13).

Note the use of "bellow" and "bull" in the poem. They allude to the unnecessary use of force, and by extension, violence by colonists against the natives. In other words, the whiteman is seen as behaving like a bull, and by inference, a bully.

In the above examples, pioneer African poets have been shown to have used the prevailing colonial situation at the time as subject-matter of poetry. They are so called 'pioneers' because their works represented the first major, serious attempts by Africans within the continent to write modern poetry with modern concerns. ${ }^{2}$ Besides, chronologically, writing in the early 1920s and 1930s, their works pre-dated the main-stream of modern African poetry that took off effectively with the formation of the Negritude movement in the 1930's up to the early 1960's. Interestingly, much as these early writers were unaware of Negritude, however, their objectives were 
similar to the latter Negritude poets in the urge to project a respectable image for the Blackman as well as protest the colonial domination of Africa. In both these respects, their poetry was successful. The success of their political and cultural message can be seen in their subject-matter and diction. For example, words like "us", "black", "dark" and "ebon" as found in the above examples of representative poems represent the black/African personality. These words, too, shall be seen in the poetry of the Negritude movement. It is on the strength of this that we refer to them as pioneers, as their works represent pre-echoes of the Negritude phase in African poetry.

\section{The Nationalist Struggle}

The nationalist struggle actually took off immediately after World War II (1939-1945). This was a period when, occasioned by the post-war situation, colonialism, war-fare and imperialism were frowned upon by the comity of nations, through the United Nations Organisation, which itself was an offshoot of World War II. Besides, at this time, as a result of World War II, the idea of the rights of man had been propagated world-wide. As a result of this, nationalist agitation for independence and the end to colonial rule spread throughout the continent, like wild-fire. Hand-in-hand with overt political struggle was the literary-cum-philosophical basis of this struggle Negritude. Negritude was the affirmation of the black personality and black culture as a way of countering European denigration and distortion of black history and culture. During this period (i.e. the ' 40 s to early ' $60 \mathrm{~s}$ ) this literary struggle became quite pronounced, especially among the Francophone poets of West, Central Africa and the Malagasy Republic. Stressing the importance of this phase in African literature, Frantz Fanon rationalizes:

In Africa, the native literature of the last twenty years is not a national literature but a Negro literature. The concept of Negro-ism, for example, was the emotional if not the logical antithesis of that insult which the white man flung at humanity. This rush of Negro-ism against the white man's contempt showed itself in certain spheres to be the one idea capable of lifting interdictions and anathemas. Because the New Guinean or Kenyan intellectual found himself above all, up against a general ostracism and delivered to the combined contempt of their overlords, their reaction was to sing praises in admiration of each other. The unconditional affirmation of African culture has succeeded the unconditional affirmation of European culture. On the whole, the poets of Negro-ism oppose the idea of an old Europe to a young Africa, tiresome reasoning to lyricism, oppressive logic to high-stepping nature, and on one side stiffness, ceremony, etiquette and skepticism, while on the other frankness, liveliness, liberty and why not? - luxuriance (1980: 171).

\subsection{The Negritude Phase}

Prominent among Negritude poets of the time were Leopold Senghor, Birago Diop and David Diop; there were also Bernard Dadie and Tchicaya U' Tamsi, among others. In the poems of these poets, stress was placed not only on the political theme, but also on the cultural and philosophical orientations of the Blackman. There was a careful cultivation of African imagery, symbols and speech cadences to bring out the Negritude concerns. Examples are Senghor's "I will Pronounce Your Name", and "Black Woman"; David Diop's "Africa" and "The Vultures"; and Birago Diop's "Viaticum".

Senghor is noted as one of the founders of the Negritude movement. In his idealization of Africa, he depicts Africa symbolically as a woman. In his poem "Black Woman", Senghor sees Africa as being the symbol of beauty and life. Like the woman that Africa is, she is gentle. Her nakedness represents her purity and innocence - all qualities that strike the persona of the poem, who is an ardent admirer:
Naked woman, black woman
Clothed with your colour which is life,
with your form which is beauty!
in your shadow I have grown up; the
gentleness of your hands was laid over my eyes.
And your beauty strikes me to the heart
like the flash of an eagle.

After looking at the various body parts and qualities, (e.g. voice, mouth, breath, skin and eyes) of his beloved woman (Africa), which the lover compares to other beautiful objects, he ends on a declamatory note that re-states the ideal and laments its evanescence: 
form I fix in the /Eternal,

Before jealous Fate turn you to ashes

to feed the/roots of life (WAV, pp. 96-97).

Similarly, in "I will pronounce Your Name", Africa is symbolized as a woman, and the persona, her lover. Here, too, the subject-matter is the praise of the African personality. And as a charmed lover, the poet-persona over-flows with praises:

I will pronounce your name, Naett, I will

declaim you, Naett!

Naett, your name is mild like cinnamon,

it is the fragrance in/which the lemon

grove sleeps,

Naett, your name is the sugared clarity

of blooming coffee trees

And it resembles the savannah, that blossoms

forth under the/masculine ardour of the /midday sun.

In the poem the persona makes use of sensuous images and the atmosphere is that of warmth: warmth that matches the intensity of the persona's love for the woman in question - Africa. And like in the previous poem, this poem ends in an affirmation of the persona's intention - that of remaining an enthralled troubadour for ever:

I am your hero, and now I have become your

sorcerer, in order to/pronounce your names.

Princess of Elissa, banished from Futa on the fateful day.

(A Selection of African Verse, p. 28).

Furthermore, David Diop, in his "Africa”, idealizes Africa:

Africa my Africa

Africa of proud warriors in the ancestral savannas

But in doing so, the poet-persona also re-states the black history of slavery, suffering, the idea of colonial oppression, pain and subjugation:

Your black blood spilt over the fields

The blood of your sweat

The sweat of your toil

The toil of slavery

The slavery of your children

Africa, tell me Africa

Are you the back that bends

Lies down under the weight of humbleness?

The trembling back striped red

That says yes to the sjambok on the roads of noon?

There is at this point a projection of the future liberation of the continent in spite of the present oppression:

... That tree that grows

There splendidly alone among white and faded flowers

Is Africa, your Africa.

With patience and stubbornness puts forth new shoots

Slowly its fruits grow to have

The bitter taste of liberty' (A Book of African Verse, p. 29). 
Also, in "The Vultures", David Diop recounts Africa's first contact with colonialism. The vultures are used symbolically to represent the European colonialists. And in this image of the vulture is implied the violent manner with which Africa was acquired by Europe through conquest and evangelization:

... When civilization kicked us in the face

When holy water slapped our cringing brows

The vultures built in the shadow of their talons

The bloodstained monument of tutelage (ABAV, p.29).

After depicting the painful memories associated with colonial rule, he goes on to express hope of liberty in spite of everything:

But we who fertilise the womb of the earth

In spite of your songs of pride.

In spite of the desolate villages of torn Africa

Hope was preserved in us as in a fortress

Spring will be reborn under our bright steps (WAV, p. 110).

This paper has tried so far, to highlight the Negritude poets vis-à-vis the political concerns of their time. Note has also been made of their use of methods that recall the traditional oral art of Africa. This is especially so in the poems of Senghor and Birago Diop. For example, Senghor's poems can be played to the accompaniment of traditional musical instruments - the Kora and the Bala fong - thus, recalling the griot tradition of West Africa. ${ }^{3}$ Also noted is their use of African imagery and symbols.

It is a well-known fact of history that the Anglophone poets never subscribed to the philosophy of Negritude. But interestingly, many of them wrote poetry that recalls this philosophy. An example is Gabriel Okara in his "Piano and Drums". In this poem Okara skillfully exposes the theme of colonialism and the clash of cultures by symbolizing European culture and education as a "piano", and African culture as a "drum". The issue is that of the cultural dilemma of the modern educated African. While the African responds to his traditional culture with his fundamental being, he at the same time responds to Western culture, through his education. He, therefore, hangs in limbo, and remains unreconciled to both:

And I lost in the morning mist of an age at a riverside keep wandering in the mystic rhythm of jungle drums and the concerto. (WAV, p. 36).

Another poet of note is Kofi Awoonor in "The Weaver Bird". In this poem, the negative effects of colonization through evangelization are lamented. European culture and religion is depicted symbolically as a weaver bird while African culture is depicted as a great tree. From the poem we see that the weaver bird defiles the tree and shrine with its droppings leaving the original owners in a search for new beliefs:

We look for new homes every day,

For new altars we strive to re-build

The old shrines defiled from the weaver's excrement.

(WAV, $p .77$ )

There are similarities between the above-cited poems by Anglophone poets and those of Negritude poets of French expression, in spite of Soyinka's "Tigritude" pronouncement. ${ }^{4}$

\section{The Post-Independence Period}

The post-independence era started from the early 1960s until present day. What has been the lot of the common man in the society? How far has he achieved the aims of independence? In the bid to tackle this socio-political issue, Negritude as a literary ideology had to be dropped. Poets each had to search and adopt various approaches or visions. But for convenience, in West Africa, Anglophone poets of the period have been divided into two sub-groups:

(a) The older generation (1960-70) and

(b) The younger generation (1970 - to date) 


\subsection{The Older Generation}

The first generation is made up of the early poets whose vision was private and individualistic, or who at best, only showed social concern, but never preached revolution. These were poets who were bitterly enraged after realizing the corruption of politicians and their betrayal of the hopes of the masses. An example is Ghana's Kwesi Brew. In his "A Plea for Mercy", the persona addresses the political potentate who, having promised the people, dashes their hopes on gaining political power:

The peasants home, from their labours

Sit by their log-fires

Telling tales of long-ago

Why should we the sons of the land

Plead unheeded before your shrine?

The lot of the common man does not interest a leader who has been elevated to a potentate and only expects worship from the crowd. So that even when the common crowd comes to worship, at the same time their penurious plight is made known as in the first and last lines of the poem:

\section{We have come to your shrine to worship \\ We the sons of the land.}

but we have come in tattered penury.

Begging at the door of the Master.

(WAV, p. 44)

In the above poem, the poet has a strong dose of societal concern (which is a pre-echo of the poets of the 70's and 80 's) but his vision is individualistic as aforesaid, because it suggests no means of societal salvation. It is still on this note that he jubilates in the next poem when the potentate is overthrown, in his poem, "A Sandal On the Head". The title "is a proverbial allusion to the Akan customary rite of signifying the destoolment of a chief by touching his head with his sandals" (Angmor 1984: 14); also, the sub-title," 24 February 1966", recalls Nkrumah's overthrow in Ghana. In the poem, the zenith of the political fortunes of the potentate is highlighted:

The Master of the house cracked his whip

In the realm of laughter and light,

And mopped his brow with a silken cloth.

The above is sharply contrasted with his final penurious state, as a result of his dethronement:

And the Master of the House

Now Master of Rags

Stays behind the rocks

To rummage in the rubbish heap

For cast-away morsels of power!

(A Selection, p. 85).

Still in West Africa, Nigeria's Christopher Okigbo is a good example of a poet whose subject-matter is politics, but whose vision is individualistic, and even obscurantist. ${ }^{5}$ For instance, the political crisis in Nigeria soon after independence provides material for many of his poems. But his diction and some of his images make his vision private. For example, in his "Lament of the Silent Sisters II", he decries the political chaos both in Nigeria in 1965, and in Africa as a whole, as illustrated by the Congo crises:

\section{THIS SHADOW of Carrion incites}

and in rhythms of silence

Urges us, gathers up our broken

hidden feather-of-flight,

To this anguished cry of Moloch (Labyrinths, p. 40). 
Only those who share the poet's intellectual intensity could know what he is talking about in this poem. Nevertheless, he predicts the military intervention and civil war that were to follow in both nations shortly after :

What cast-iron steps cascading down the valley

all forged into thunder of tanks;

And detonators cannoned into splintered flames

in this jubilee dance of fire-flies! (Labyrinths, p. 40)

It is pertinent to note that in his "Path of Thunder" sequence, Okigbo was fully involved in highlighting the events that led to the Nigerian civil war: the failure of the politicians, and the failure of the three regions to come to a compromise over many issues. So, his prediction of war was prophetic, as can be seen in his "Come Thunder"

NOW THAT the triumphant march has entered the last street corners,

Remember, $O$ dancers, the thunder among the clouds...

Now that laughter, broken in two, hangs tremulous between

the teeth,

Remember, $O$ dancers, the lightening beyond the earth...

The arrows of God tremble at the gates of light,

The drums of curfew pander to a dance of death;

And the secret thing in its heaving

Threatens with iron mask

The last lighted torch of the century ...

(Labyrinths, p. 66).

When the first coup d'état takes place in January 1966, Okigbo is elated as shown in his "Hurrah for Thunder":

WHATEVER happened to the elephant-

Hurrah for thunder -

But amidst his jubilant state he recalls the ever-recurring decimal of broken political promises, and goes on to caution himself not to comment on what he sees: especially as the new rulers were already disagreeing on how to share the "loot"! With such a disgusting state of affairs, the poet feels it necessary to keep what he does to himself in order not to be noticed:

But already the hunters are talking about pumpkins:

If they share the meat let them remember thunder.

Today for tomorrow, today becomes yesterday:

How many million promises can ever fill a basket...

If I don't learn to shut my mouth I'll go to hell,

I, Okigbo, town-crier, together with my iron bell (Labyrinths, p. 67).

\subsection{The Younger Generation}

In the case of the younger generation of West African poets, their political concern is closely tied to their vision which is masses-oriented. They distinguish themselves as the champions of the masses' plight. And since their poetry is for the masses, their diction is much simpler, so that even the least educated man in the society can read and understand their poems. Representative of these writers with a socialist vision are Ghana's Kofi Anyidoho and Nigeria's Niyi Osundare. Niyi Osundare demonstrates his socialist vision of society in the epigraph of his collection, Songs of the Marketplace (1983):

\section{"I made an unbreakable pledge to myself,}

That the people would find their voices in 
my song",

The above was an epigraph derived from Pablo Neruda. Also, in his closing lines, he reiterates his socialist vision, which is to change society:

I sing

Of the end

of warlords and armories

and prisons of hate and fear

I sing of a world reshaped (p. 90).

Likewise in Anyidoho's Elegy for the Revolution (1978), socialist commitment comes out in the dedication below:

\title{
To the memory of \\ The Revolution that went astray and for \\ Those who refused to die/Aluta Continua
}

This is a reference to the Acheampong regime in Ghana between 1971 and 1978, which let down the people once again. And because of this disappointment, Anyidoho prophetically foresaw the coming of the Rawlings Revolution that was to sweep-off Acheampong and his cohorts through firing squad as part of the cleansing and nation-rebuilding process, in his "A Dance of Death":

\author{
Let us celebrate our \\ death by firing squads \\ To beats of martial strains \\ Let us link our arms \\ On these public fields of blood \\ teach our feet to do the dance of death...
}

It is on the field of execution

That death embraces life

This is our ritual celebration

of marriage of death to life...

The process of reconstruction is also

A process of demolition (Anyidoho 1978)

The accuracy of this prediction cannot be doubted, as the poem was written in 1976, and the event took place by the end of the " $70 \mathrm{~s}$.

\section{East, Central and South Africa}

Focus now shifts to East, Central and South African poetry. Poetry from these regions is more or less politically committed poetry. The reason in the case of South Africa of the 70's - early 90's was the Apartheid political set-up. In South-West Africa, with special reference to Angola, a situation similar to South Africa prevailed; the Portuguese continued to maintain their colonial domination of the country until 1975, in spite of International public opinion. The painful attempt by the Portuguese authorities to continue suppressing the natives resulted in an outflow of poetry which was at once violent (as part of the struggle for independence) and Negritudist.

\subsection{Angolan/Lusophone Poetry}

At the height of the Angolan people's struggle for independence, Agostinho Neto's poems came to be reckoned 
with as part of the people's struggle. Two examples are his "Western Civilisation" and "Departure for forced labour".

"Departure for forced labour" depicts the brutalization of the Africans who are forcefully taken away from their homes to distant plantations to work under slave-conditions, probably for life. In other words, it was a modern form of slavery and inhumanity. In this poem, the persona is narrating the trauma of a woman whose husband has been forcefully taken to São Tomé to perform forced labour. The description of the woman begins with the suffering boldly written on her face:

\section{The face depicts the soul}

Creased with suffering

In this vespertine and bloody

Hour of weeping

Manuel

her love

left for São Tomé

beyond the sea.

No mention of the man's return is made. But rather, the despair, loss of hope and general bleakness of the surroundings is described as mirroring what goes on in her inner self:

Until when?

Far on the horizon suddenly

the sun and the ship

are drowned

in the sea darkening

the sky darkening the earth

and the woman's soul

The bleakness of the situation is further stressed and underscored at the end:

There is no light

no stars in the dark sky

Everything on earth is shadow

There is no light

no north in the woman's soul

Blackness

Only blackness.

In the poem "Western Civilization", the concern is a satire on the slave conditions and penury in which the average Blackman lives, the suffering and battery he undergoes and his death without anything to show for; the spot-light is first on the shack in which he lives:
Tins fixed to stakes
driven in the earth
make the house

His clothes and house-covering also come in:

Rags complete
the intimate landscape.

Then comes his job description, which is hard and back- breaking:

The sun piercing the cracks

awakens the inhabitant 
After twelve hours of slave

labour

Breaking stones

Carrying stones

Breaking stones

Carrying stones

in the sun

in the rain

breaking stones

carrying stones

Because of the tediousness of his job, ageing comes faster than it should, and death by malnutrition and starvation is the outcome:

$$
\begin{aligned}
& \text { Old age comes fast } \\
& \text { A reed mat on dark nights } \\
& \text { enough for him to die on } \\
& \text { thankfully } \\
& \text { and of hunger. }
\end{aligned}
$$

This last section of the poem is quite biting. It shows the anger of the persona at the plight of his people. It bitterly scorns the situation as the only "benefit" of Western civilization that Africans have gained in their colonial history. In spite of this condition Neto's poems hold out a hope for liberation and freedom; this is embodied in the title of the collection, A Sacred Hope (1974).

\subsection{Poetry in East Africa}

Poetry in East Africa has been largely the expression of concern over those social issues that depict the masses' plight, after the gaining of independence. The common man has been pushed to the position of a donkey that is over-worked but which is only given just enough to keep it alive only, so that it can work again the next day; and this, for his fellow compatriots now in position of rulership! An example of this can be found in Crispin Hauli's "The Song of the Common Man":

They drive me along

They do they do

These my brothers, no longer brothers-

Their hands are whips, along they drive me,

No longer am I the same mother's child.

They kick me along,

they do they do,

These my playmates no longer playmates-

Their actions are fates, my life they decide,

No longer am I the same free-born human

They abuse me,

They do time and again

Fellow humans load me with all their bundles -

They are my masters, and me a poor ass,

To be driven, pushed, kicked and abused. 
(Poems from East Africa, p. 49)

Another example from East Africa is Richard Ntiru's "Pauper". This poem takes a direct swipe at the new political elite of Africa who have conspired to keep the common man in a continuous state of poverty, deprivation and misery. Opening the poem with rhetorical questions, parodying William Blake's "The Tiger", the poet makes his point plain:

Pauper, pauper, craning your eyes

In all directions, in no direction!

What brutal force, malignant element,

Dared to forge your piteous fate?

Was it worth the effort, the time?

He contrasts the common man's miserable state of deprivation with the luxury of the ruling elite, symbolized by their "paunch" (a protruding stomach as a sign of over-consumption):

And when he looks at the grimy coating

Caking off your emaciated skin,

At the rust that uproots all your teeth

Like a pick on a stony piece of land,

Does he pat his paunch at the wonderful sight?

Even the common man's representative (from the ruling elite) shows an extreme lack of concern:

And your M.P. with a shining head and triple chin

Will mourn your fate in a supplementary question

at Question Time

(Poems from East Africa, pp. 114-115).

Okot p'Bitek reinforces the East African poets' concern for the welfare of the masses, when he makes Lawino in his Song of Lawino, to make the following remarks about the irresponsibility of the political leaders:

And while the pythons of sickness

Swallow the children

And the buffaloes of poverty

Knock the people down

And ignorance stands there

Like an elephant/The war leaders

Are tightly locked in bloody/feuds

Eating each other's liver...

(Song of Ocol, p. 111).

This is a telling comment on the elite's abandonment of the people's struggle for the struggle for their selfish interests.

\subsection{Poetry in South Africa}

Poetry in South Africa has been, like in East Africa, to further the cause of the deprived and oppressed masses this time the black oppressed people. This situation of racist oppression - Apartheid - has forced South African poets to write poems depicting its gory aspects to the world, in a bid to muster world disapproval for it, which would lead to its dismantling. Oppression, brutality, pain and unmitigated suffering of the masses is aptly depicted in Dennis Brutus' "This sun on this rubble". Physical battery and torture are here highlighted:

... Bruised though we must be

Under jackboots our bones and spirits crunch 
forced into sweat-tear-sodden slush

- now glow-lipped by this sudden touch:

But in spite of battery and torture, the people are unyielding, resilient, and with the hope of revenge upon their white torturers:
... our bones may later sing
or spell out some malignant nemesis
Sharpevilled to spear points for revenging
(A Selection of African Verse, $p .58$ )

Another example from South Africa is O.M. Mtshali's "The Master of the House". This poem takes a satirical look at the apartheid system in which the white minority are the masters while the black majority are the servants, doing degrading menial jobs. But even under this condition the blacks have learnt to survive and outwit the inhuman system:

Master I am a stranger to you

But will you hear my confession?

I am a faceless man

Who lives in the backyard/of your house

I share your table/so heavily heaped with

bread, meat and fruit/it huffs like a horse

drawing a coal cart.

The master's luxury above contrasts sharply with the deprivation of the persona; a situation not unlike the Biblical parable:

As the rich man's to Lazarus,

the crumbs are swept to my lap/by my Lizzie:

'Sweetie! Eat and be satisfied now,

Tomorrow we shall be gone'.

The last two lines above demonstrate the precariousness of life for the blackman in South Africa, and also bring out the South Africans' seeming consciousness of time. Nevertheless, the Blackman seems somehow to live with the system by outsmarting and spooking it, but this also underscores his consciousness of the time element:

So nightly I ran the gauntlet,

wrestle with your mastiff, Caesar,

for the bone pregnant with meat

and wash it down with Pussy's milk.

I am the nocturnal animal

that steals through the fenced lair/to meet my mate

and flees at the break of dawn

before the hunter and the hounds/run me to ground.

(Sounds of a Cowhide Drum, p. 55).

\section{Recent Echoes from a Globalised Africa}

While politics has remained the informing spirit of African poetry, recent echoes from a now globalised world have shifted emphasis away from the politics of rulership to the politics of the preservation of the environment cum ecosystem and concern for the masses' survival in the face of natural and man-induced disasters. In other words, environmental issues have now become global concern. This shift in emphasis is manifested in the poetry of the younger generation of poets in Nigeria like Niyi Osundare, Tanure Ojaide, Joe Ushie and Ibiwari Ikiriko, among many others. These poets and their younger acolytes decry the mindless exploitation of the land thus leading to environmental degradation and disaster in which it is the masses that are the end-sufferers. In his poem "Ours to Plough, Not to Plunder", Osundare decries the destruction of the natural environment by those 
who should protect it. The poem reminds us that the responsibility of keeping the environment safe belongs to us all:

\section{This earth is}

Ours to work not to waste

Ours to man, not to maim

Ours to plough, not to plunder.

Also, in his opening poem "Hill Songs", in the anthology of that name, Joe Ushie laments the devastation of the environment by anthropogenic forces:

But by axe and flame

You stand undressed, nude

Like anthill at the market place...

These lines suggest inordinate destruction of the ecosystem especially the forests, through the use of the axe (forest clearing to make space for housing) and flame (forest clearing for agriculture). Another case in point is "Volcano 2" in Hill Songs:

\section{Tall and invincible}

Are the hills;

Low and fragile

Are the vales;

But the volcano

Which chokes

The vales

Also wrecks

The crown of the hills (p. 18).

In the above poem, the poet-persona while admiring the beauty of nature as manifested in the beauty of the hills and valleys of his home environment, equally demonstrates that nature can wreak havoc against itself as symbolized by the volcano which can erupt at any time and deface the pristine beauty of the environment. In another poem, "The Hills Will Rise Again", man's predatory and destructive activities on the environment are frowned upon. An excerpt from the poem states as follows:

For too long now have the hills

stood in silence as man

skins the hills

defiles the valleys

brushes his teeth with man's femur

But this silence of the hills

is not the silence of the graveyard.

Seismic waves may rest for long

yet, in their season they come (p. 50).

In the poem above, the poet-persona demonstrates that if man does not check himself in his bid to exploit the environment, he will trigger forces of self-destruction.

In a globalised world like ours, what affects one affects all, no matter how far removed from the scene of disaster they may be. This is the ideal that informs another anthology entitled, Tsunami Blues and other Poems (2007). In this anthology, young Nigerians who have been exposed to the modern tools of information and communication technology (ICT) demonstrate their empathy for fellow humanity who were victims of the Tsunami disaster of 2004 which engulfed most of South-East Asia. An excerpt from the editor's Introduction state as follows:

On December 26, 2004, the usually calm waters of the Indian Ocean awoke the world with their menacing 
advance towards the lands of twelve countries in Asia and Africa. An earthquake, which later came to be known the world as "Tsunami", had occurred in the belly of the Ocean, resulting in the unusual flood. In no time, over 240,000 human lives, the flora and fauna, and the latifundia of the coastal settlements of the twelve littoral countries were washed into the belly of the Ocean thus submerging the whole world into a funereal mood. All of humanity was suddenly wrapped into one fear, one pain, one sorrow and one language: grief (2007 p. 7).

From the outpour of grief above, poetic beauty was born. Two excerpts of poems from the anthology above would suffice for our purposes here. In the lead poem that gives the anthology its title, "Tsunami Blues", the poet, Desmond Wilson, grieves for the victims unaccounted for as a result of the suddenness of the disaster thus:

Tsunami, Tsunami,

Why did you do this to me?

Tsunami, my grief,

Tsunami, our scourge;

Tsunami, the destroyer of our world.

Why O Tsunami?

Our flooded faces presage no tears.

Tsunami, you sold death

To unsuspecting souls,

Breached loves and histories; (p. 13).

In another poem entitled "Tsunami Reminds Us...", Ebi Yeibo restates that the disaster reminds man of the interlocking relationship of all nature as well as the fact of man's primordial helplessness and insecurity in the cosmos:

Tsunami reminds us

Of the mixed palette

Suckling nature's undying shrub

Tsunami reminds us

We stand in the middle of a maelstrom

Weaving unpredictable waters

To eke out a world

Of whammy revelations (pp. 22-3).

\section{Conclusion}

This paper set out to establish the relationship between politics and the development of poetry in modern Africa. In furtherance of this, it has traced the development of poetry and its historical link with the politics of colonialism beginning from early poems with political concerns long before the advent of Nationalism. The thread was passed through the era of Nationalism and independence struggle, and its literary philosophy of Negritude, right down to recent poetry of post-independence Africa. However, in the current globalised world driven by ICT, focus has changed to mirroring the degradation of the environment as a way of galvanizing political action towards preserving the ecosystem for the survival of man.

Attempt has also been made to illustrate the argument with representative poems from different regions of Africa. Though this treatment has been inadequate, nevertheless, what stands out is that the development of African poetry would remain tied up with different phases of political developments in Africa, now and in the foreseeable future, as a result of our colonial legacy. The pertinence of this observation is based on the perceptive remark made by Moore and Beier that the African poet seldom indulges in poetry that mirrors his private concern, but that of the community. ${ }^{7}$ This is so because the African milieu is communally-based and not individually-based. As long as this continues to be the case, so long shall poetic concerns continue to be tied to the political achievements or otherwise of the masses.

\section{References}

Angmor, C. (1984). Literature and politics in Ghana. A paper presented at the fourth international conference on 
literature and the English language, University of Calabar, May 1-5.

Anyidoho, K. (1979). Atukwei Okai and his poetic territory. In Kolawole Ogungbesan (Ed), New west African literature. London: Heinemann.

Anyidoho, K. (1982). A harvest of our dreams. London: Heinemann.

Cook, D., \& Rubadiri, D. (eds) (1971). Poems from East Africa. London: Heinemann.

Fanon, F. (1980). The wretched of the earth. London: Penguin.

Mtshali, O. M. (1972). Sounds of a cowhide drum. London: Oxford.

Neto, A. (1974). A sacred hope. London: Heinemann.

Nkosi, L. (1981). Tasks and masks. London: Longman.

Nwoga, D. I. (ed) (1976). West African verse. London: Longman.

Okigbo, C. (1979). Labyrinths. London: Heinemann.

Osundare, N. (1983). Songs of the market place. Ibadan: New Horn Press.

Osundare, N. (1986). The eye of the earth. Ibadan: Heinemann.

p'Bitek, O. (1984). Song of lawino and song of ocol. London: Heinemann.

Reed, J., \& Wake, C. (eds.) (1970). A book of African verse. London: Heinemann.

Senanu, K. E., \& Vincent, T. (eds.) (1982). A selection of african poetry. London: Longman.

Ushie, J. (2000). Hill songs. Ibadan: Kraft Books.

Ushie, J. (ed) (2007). Tsunami blues and other poems: Nigerians'tears in verse. Morrisville, NC: Handel Books.

Wauthier, C. (1978). The literature and thought of modern Africa. London: Heinemann.

\section{Notes}

1. Benibengor Blay was an early Ghanaian poet whose poetry took on the conventionalities and form of English poetry e.g. rhyme, metre, and sonnet form, for example. See Angmor, "What Vision informs African Literary Aesthetics?" A paper presented at the International Conference on African Literature and the English Language, University of Calabar, May 1988, p.6, and note 4 (p. 22).

2. Many writers have treated the subject of early literary works written by people of African origin in the diaspora, E.G. Latino, Phyllis Wheatley, Paul Lawrence Dunbar and others. See Lewis Nkosi. Tasks and Masks. London: Longman, 1981: 107-111.

3. The musical instruments to be used for each poem are indicated against the title of each poem: See Senghor, (1976) Prose and_Poetry, London, Heinemann (a.w.s. 180) by John Reed \& Clive Wake.

4. Soyinka once made a remark critical of Negritude, thus: "a tiger does not proclaim his tigritude, but he kills his prey and eats it;" quoted by Wauthier, (1978): The Literature and Thought of Modern Africa, London: Heinemann, p. 318.

5. On his obscurantism, see Chinweizu et al (1980) Toward the Decolonisation of African Literature. Enugu: Fourth Dimension, Chapter three, see also articles on Okigbo in African Literature Today, Nos. 1, 2, and 3. (Omnibus edition) (1978) E. D. Jones (ed). London and New York: Heinemann and Africana.

6. In 1965, Nigeria was torn apart by the widespread political violence of the general elections which all started in the Western regional political crisis of 1964. On the African continent, political chaos engulfed the Republic of Congo (Kinshasa) later Zaire; disagreements between the regional based parties and the centre and the consequent conflicts that resulted, led to the assassination of the Prime Minister Patrice Lumumba in 1962; and finally civil war.

7. Jahnheinz Jahn's remarks quoted by Moore \& Beier (1968) in Modern Poetry from Africa. London: Penguin, p. 23. 